Inorg Chem. 2005 March 7; 44(5): 1169-1171. doi:10.1021/ic048818z.

\title{
Role of Protons in Superoxide Reduction by a Superoxide Reductase Analogue
}

\author{
Roslyn M. Theisen and Julie A. Kovacs \\ Department of Chemistry, UniVersity of Washington, Box 351700, Seattle, Washington \\ 98105-1700
}

\section{Abstract}

Superoxide reduction by thiolate-ligated $\left[\mathrm{Fe}^{\mathrm{II}}\left(\mathrm{S}^{\mathrm{Me} 2} \mathrm{~N}_{4}(\text { tren })\right)\right]^{+}(\mathbf{1})$ involves two proton-dependent steps and a single peroxide intermediate, $\left[\mathrm{Fe}^{\mathrm{III}}\left(\mathrm{S}^{\mathrm{Me} 2} \mathrm{~N}_{4}(\mathrm{tren})\right)(\mathrm{OOH})\right]^{+}(\mathbf{2})$. An external proton donor is required, ruling out mechanisms involving $\mathrm{H}^{+}$or $\mathrm{H}$-atom abstraction from the ligand $\mathrm{N}$ $-\mathrm{H}$. The initial protonation step affording 2 occurs with fairly basic proton donors (EtOH, $\mathrm{MeOH}$, $\mathrm{NH}_{4}^{+}$) in THF. More acidic proton donors are required to cleave the $\mathrm{Fe}-\mathrm{O}$ (peroxide) bond in $\mathrm{MeOH}$, and this occurs via a dissociative mechanism. Reaction rates are dependent on the $\mathrm{p} K_{\mathrm{a}}$ of the proton donor, and a common $\left[\mathrm{Fe}^{\mathrm{III}}\left(\mathrm{S}^{\mathrm{Me} 2} \mathrm{~N}_{4}(\operatorname{tren})\right)(\mathrm{MeOH})\right]^{2+}(\mathbf{3})$ intermediate is involved. Acetic acid releases $\mathrm{H}_{2} \mathrm{O}_{2}$ from 2 under pseudo-first-order conditions ([HOAc] $=138 \mathrm{mM},[2]=$ $0.49 \mathrm{mM}$ ) with a rate constant of $8.2 \times 10^{-4} \mathrm{~s}^{-1}$ at $-78^{\circ} \mathrm{C}$ in $\mathrm{MeOH}$. Reduction of $\mathbf{3}$ with $\mathrm{Cp}_{2} \mathrm{Co}$ regenerates the active catalyst 1 .

Superoxide reductases (SORs) are non-heme iron enzymes that reduce superoxide $\left(\mathrm{O}_{2}^{-}\right)$to $\mathrm{H}_{2} \mathrm{O}_{2}$ in anaerobic microbes. ${ }^{1 \mathrm{a}-\mathrm{j}}$ The catalytically active form of this enzyme contains reduced $\mathrm{Fe}^{2+}$ ligated by four $\mathrm{N}^{\text {his }}$ and a $\mathrm{S}^{\mathrm{cys}}$ trans to an open coordination site (Figure 1). ${ }^{1 \mathrm{~h}, \mathrm{i}}$ The oxidized SOR resting state contains a highly conserved Glu- $\mathrm{CO}_{2}-\left({ }^{-14} \mathrm{Glu}\right.$ or $\left.{ }^{47} \mathrm{Glu}\right)$ coordinated to this site. ${ }^{1 \mathrm{c}, \mathrm{e}, \mathrm{h}}$ Upon reduction, this $\mathrm{Glu}-\mathrm{CO}_{2}{ }^{-}$dissociates to regenerate the open binding site necessary for catalysis (reaction 3, Figure 1). The mechanism by which SOR is proposed to reduce superoxide has been controversial, particularly with regard to the number of intermediates involved. ${ }^{1 \mathrm{a}, \mathrm{b}, \mathrm{e}, \mathrm{g}, 2}$ It is generally agreed that the mechanism involves initial coordination of $\mathrm{O}_{2}{ }^{-}$to the open coordination site and is thus inner-sphere. ${ }^{\text {If }}$ After this step, two intermediates are observed in the reaction between $D$. baarsii SOR and $\mathrm{O}_{2}{ }^{-1},{ }^{\mathrm{b}, 2}$ whereas only one intermediate is observed in the reaction between D. Vulgaris SOR and $\mathrm{O}_{2}{ }^{-.1 \mathrm{a}, \mathrm{e}, \mathrm{g}}$ DFT calculations indicate that an end-on Fe $\mathrm{Fe}^{\mathrm{III}}-\mathrm{OOH}$ intermediate is most likely involved. ${ }^{\mathrm{g}}$ It has been suggested that the nearby $47 \mathrm{Glu}-\mathrm{CO}_{2}{ }^{-}$displaces peroxide from the final intermediate. ${ }^{1 b, c}$ However, it is not clear whether the Glu-bound state is involved in the catalytic cycle or whether a solvent-bound form ${ }^{1 \mathrm{a}}$ would be catalytically more competent. Protons clearly play an important role in the SOR mechanism. The source of protons (in both the first and second protonation steps) has also been a point of

\footnotetext{
*To whom correspondence should be addressed. kovacs@chem.washington.edu.

Supporting Information Available: Experimental section describing compound preparation; kinetic plot for 2 + HOAc (Figure S-1); electronic absorption spectra showing $\mathrm{HClO}_{4}$-induced conversion of $\mathbf{2}$ to $\mathbf{3}$ (Figure S-2), $\mathrm{HBF}_{4}$-induced conversion of $\mathbf{6}$ to 3 (Figure $\mathrm{S}-3$ ), and $\mathrm{HBF}_{4}$-induced conversion of $\mathbf{2}$ to $\mathbf{3}$ (Figure S-4). This information is available free of charge via the Internet at http:// pubs.acs.org.
} 
discussion. Under acidic conditions, ${ }^{14} \mathrm{Glu}-\mathrm{COOH}$ has been proposed to serve as a proton source. ${ }^{1 \mathrm{a}, \mathrm{e}}$ Solvent was shown to provide protons in the D. baarsii SOR mechanism. ${ }^{\mathrm{b}} \mathrm{A}$ highly conserved Lys- $\mathrm{NH}_{3}{ }^{+}$residue $\left({ }^{15} \mathrm{Lys}\right.$ or $\left.{ }^{48} \mathrm{Lys}\right)$, essential for catalytic activity, ${ }^{2}$ has been shown to affect rates of $\mathrm{H}_{2} \mathrm{O}_{2}$ formation, thus suggesting its involvement in the mechanism. ${ }^{1 \mathrm{a}, 2} \mathrm{~A}$ condensed version of the SOR mechanism is presented in Figure 1.

The active site of SOR closely resembles that of $\mathrm{P} 450,{ }^{3}$ and both enzymatic mechanisms are proposed to involve an $\mathrm{Fe}^{\mathrm{III}}-\mathrm{OOH}$ intermediate and initial protonation of the distal oxygen. The site to which the second proton is delivered, as well as the spin state, ${ }^{4 \mathrm{~b}}$ determines whether the $\mathrm{Fe}-\mathrm{O}$ or $\mathrm{O}-\mathrm{O}$ bond is cleaved. ${ }^{4 \mathrm{a}-\mathrm{c}}$ Double protonation of the distal oxygen and an $S=1 / 2$ spin state ${ }^{4 \mathrm{~b}}$ would result in heterolytic $\mathrm{O}-\mathrm{O}$ bond cleavage to form $\mathrm{H}_{2} \mathrm{O}$ and a high-valent $\mathrm{Fe}^{\mathrm{V}}=\mathrm{O}$ species, whereas protonation of the proximal oxygen and an $S=5 / 2$ spin state, would result in $\mathrm{Fe}-\mathrm{O}$ bond cleavage to afford $\mathrm{H}_{2} \mathrm{O}_{2}$. The only observed peroxide in SOR is $S=5 / 2$ (generated via $\mathrm{H}_{2} \mathrm{O}_{2}$ addition to a Glu $\rightarrow$ Ala mutant), ${ }^{\text {cc }}$ thus it is likely that $\mathrm{H}_{2} \mathrm{O}_{2}$ release by $\mathrm{SOR}$ involves protonation at the $\mathrm{Fe}^{\mathrm{III}}-\mathrm{OOH}$ proximal oxygen.

Our group has demonstrated that thiolate-ligated $\left[\mathrm{Fe}^{\mathrm{II}}\left(\mathrm{S}^{\mathrm{Me} 2} \mathrm{~N}_{4}(\text { tren)) }]^{+}\right.\right.$(1) (Figure 2) will react with $\mathrm{O}_{2}{ }^{-}$in $\mathrm{MeOH}$ at low temperatures to generate the first synthetic example of an $\mathrm{Fe}^{3+}-\mathrm{OOH}$ species containing sulfur in the coordination sphere, $\left[\mathrm{Fe}^{\mathrm{III}}\left(\mathrm{S}^{\mathrm{Me} 2} \mathrm{~N}_{4}(\right.\right.$ tren $\left.)\right)$ $(\mathrm{OOH})]^{+}(\mathbf{2}) .{ }^{5 \mathrm{a}, \mathrm{b}}$ Intermediate 2 is low-spin $(S=1 / 2)$ and displays a $v_{\mathrm{O}-\mathrm{O}}$ at $784 \mathrm{~cm}^{-1}$ (that shifts to $753 \mathrm{~cm}^{-1}$ upon isotopic labeling with ${ }^{18} \mathrm{O}_{2}^{-}$), a charge-transfer transition at 455 (2900) nm, and a coordinated diatomic oxygen ligand with one short, and one long Fe-O distance at 1.86(3) and 2.78(3) $\AA$, respectively, as determined by EXAFS. ${ }^{5 a}$ The chargetransfer transition associated with 2 is unusually high in energy for a $\mathrm{S} \rightarrow \mathrm{Fe}$ (III) CT transition. 6,7

In this work, we explore the addition of proton and electron sources to our functional model $^{5 \mathrm{a}}$ in order to model reaction steps $1-3$ of the proposed SOR mechanism (Figure 1). Pre-isolation and purification of the extremely air sensitive $\mathrm{Fe}^{\mathrm{II}}$ precursor, $\mathbf{1}$, has afforded a much cleaner reaction system and a significantly more stable $\mathrm{Fe}^{\mathrm{III}}-\mathrm{OOH}(\mathbf{2})$ species, thus allowing us to probe its reaction chemistry. ${ }^{8} \mathrm{We}$ can separately monitor the first and second protonation steps involved in $\mathrm{H}_{2} \mathrm{O}_{2}$ formation by our model, but this requires the use of two different solvents. The first protonation step is most effectively monitored in THF, whereas the second protonation step is cleanest when monitored in $\mathrm{MeOH}$. In rigorously dried THF, no reaction is observed between prepurified $\mathbf{1}$ and $\mathrm{O}_{2}^{-}$(solubilized as the $18-\mathrm{cr}-6-\mathrm{K}^{+}$salt) until an external proton source is added (Figure 2). ${ }^{8}$ This rules out a mechanism involving $\mathrm{H}^{+}$or $\mathrm{H}$-atom abstraction ${ }^{9}$ from the ligand N-H's. Addition of a proton source such as $\mathrm{NH}_{4}{ }^{+}, \mathrm{MeOH}$, or EtOH to a mixture containing prepurified $\mathbf{1}+1$ equiv of $\mathrm{O}_{2}^{-}$in THF at $-78{ }^{\circ} \mathrm{C}$ rapidly affords our metastable hydroperoxide species $\left[\mathrm{Fe}^{\mathrm{III}}\left(\mathrm{S}^{\mathrm{Me} 2} \mathrm{~N}_{4}(\text { tren })\right)(\mathrm{OOH})\right]^{+}$ (2). Rates of 2 formation are dependent on the $\mathrm{p} K_{\mathrm{a}}$ of the proton donor: for the reaction to occur at comparable rates, the concentration of EtOH has to be $\sim 500$ times higher than that of $\mathrm{NH}_{4}{ }^{+}$. Although the $\mathrm{p} K_{\mathrm{a}}$ 's (both relative and absolute) of these proton donors are likely to differ dramatically in THF ( $\mathrm{vs}_{2} \mathrm{O}$ ), the fact that $\mathrm{EtOH}$ will protonate 2 suggests that the initial protonation site is rather basic. ${ }^{10,11}$ The proton dependence of $\mathbf{2}$ formation, along with 
the unusually high energy of the $\mathrm{S} \rightarrow \mathrm{Fe}$ (III) charge-transfer band ${ }^{6}$ and the highly ordered distal oxygen observed by EXAFS, ${ }^{5 a}$ suggests that the distal peroxide oxygen is protonated and perhaps hydrogen-bonded to the thiolate. A hydrogen-bonded ring structure (Figure 2) might, in fact, provide a driving force for the formation of hydroperoxide-ligated $\mathbf{2}$.

The second protonation step in the reduction of superoxide by our model requires stronger acids, such as $\mathrm{HOAc}, \mathrm{HBF}_{4}$, or $\mathrm{HClO}_{4}$. Weaker acids [ $\mathrm{NH}_{4}{ }^{+}$(a Lys analogue) and $\mathrm{MeOH}$ ] do not release $\mathrm{H}_{2} \mathrm{O}_{2}$ from 2 in $\mathrm{MeOH}$. Reactions involving acids with noncoordinating anions $\left(\mathrm{HBF}_{4}\right.$ or $\left.\mathrm{HClO}_{4}\right)$ cleanly afford a common eggplant purple intermediate $\left(\mathbf{3}, \lambda_{\max }\right)=$ $565 \mathrm{~nm}$, Figures S-2 and S-4) in $\mathrm{MeOH}$ at $-78{ }^{\circ} \mathrm{C}$. This purple intermediate 3 is also observed when $\mathrm{HBF}_{4}$ is added to $\left[\mathrm{Fe}^{\mathrm{III}}\left(\mathrm{S}^{\mathrm{Me} 2} \mathrm{~N}_{4}(\text { tren })\right)(\mathrm{OMe})\right]^{+}(\mathbf{6})^{5 \mathrm{a}}$ at $-78{ }^{\circ} \mathrm{C}$ (Figure S-3), suggesting that 3 is the protonated, dicationic, methanol-bound species $\left[\mathrm{Fe}^{\mathrm{III}}\left(\mathrm{S}^{\mathrm{Me} 2} \mathrm{~N}_{4}(\right.\right.$ tren $\left.)\right)$ $(\mathrm{MeOH})]^{2+}$ (Figure 2). Acetic acid reacts with peroxide-bound 2 (Figure 3) also to afford $\mathbf{3}$, which then converts to acetate-bound $\left[\mathrm{Fe}^{\mathrm{III}}\left(\mathrm{S}^{\mathrm{Me} 2} \mathrm{~N}_{4}(\text { tren })\right)(\mathrm{OAc})\right]^{+}(\mathbf{4})$ upon warming. ${ }^{12}$ It is likely that glutamic acid-promoted $\mathrm{H}_{2} \mathrm{O}_{2}$ release by SOR (reaction 2, Figure 1) occurs via a similar mechanism involving a solvent-bound intermediate. Under pseudo-first-order conditions $([\mathrm{HOAc}]=138 \mathrm{mM},[\mathrm{Fe}-\mathrm{OOH}]=0.49 \mathrm{mM})$, our peroxide species 2 reacts with HOAc with a rate constant of $8.2 \times 10^{-4} \mathrm{~s}^{-1}$ at $-78{ }^{\circ} \mathrm{C}$ in $\mathrm{MeOH}$. Reaction rates are dependent on the $\mathrm{p} K_{\mathrm{a}}$ of the proton donor; reactions are complete in seconds with stronger acids $\left(\mathrm{HBF}_{4}, \mathrm{HClO}_{4}\right)$ vs hours with $\mathrm{HOAc}$. The fact that a common $\mathrm{MeOH}$-bound intermediate 3 is observed in these reactions suggests that $\mathrm{H}_{2} \mathrm{O}_{2}$ release occurs via a protoninduced dissociative mechanism. An associative mechanism involving nucleophilic displacement is ruled out by the fact that $\mathrm{NH}_{4}{ }^{+} \mathrm{OAc}^{-}$does not release $\mathrm{H}_{2} \mathrm{O}_{2}$ from 2 in $\mathrm{MeOH} .{ }^{13}$ That a similar mechanism is involved in the second protonation step of SOR is supported by the fact that the initial product observed during the decay of the SOR peroxide $(600 \mathrm{~nm})$ intermediate (under basic conditions) appears to lack a coordinated glutamate and is suggested to be five-coordinate or solvent-bound. ${ }^{1 \mathrm{a}}$

To mimic the last step in the SOR mechanism (reaction 3 of Figure 1), $\mathrm{Cp}_{2} \mathrm{Co}$ was added as an electron source to the oxidized $\mathrm{Fe}^{\mathrm{III}}$ intermediate $\mathbf{3}$, which forms upon HOAc-induced $\mathrm{H}_{2} \mathrm{O}_{2}$ release from 2 . This resulted in the regeneration of reduced $\left[\mathrm{Fe}^{\mathrm{II}}\left(\mathrm{S}^{\mathrm{Me} 2} \mathrm{~N}_{4}(\text { tren })\right)\right]^{+}(\mathbf{1})$, which subsequently reacts with superoxide to afford the peroxide intermediate $\mathbf{2}$. Thus far, we have achieved eight turnovers under these conditions, and we are working on optimizing this catalytic reaction. The key to achieving higher turnovers will require the removal of the $\mathrm{H}_{2} \mathrm{O}_{2}$ released in the reaction so as to avoid peroxide-induced decomposition of the iron complex.

In conclusion, the work reported herein demonstrates that superoxide reduction by our thiolate-ligated model complex involves two proton-dependent steps involving a single

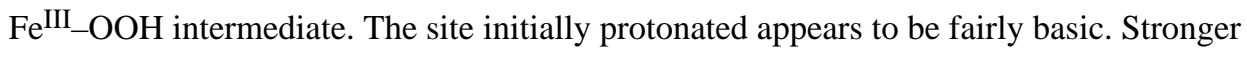
acids are required to cleave the $\mathrm{Fe}-\mathrm{O}$ (peroxide) bond and release $\mathrm{H}_{2} \mathrm{O}_{2}$, which occurs via a dissociative mechanism. ${ }^{13}$ A similar mechanism is most likely involved in $\mathrm{H}_{2} \mathrm{O}_{2}$ release from the SOR enzyme. ${ }^{1 \mathrm{a}}$ The proton dependence of the first step of our mechanism agrees with Sawyer's reported thermodynamic and kinetic data for superoxide-induced oxidation reactions ${ }^{10}$ but differs from that of SOR. ${ }^{1 \mathrm{a}, \mathrm{b}}$ The cis, instead of trans, arrangement between the thiolate and the peroxide of our model, versus the enzyme, might be responsible for the 
mechanistic differences between our model and the enzyme. The fact that we observe only one (hydro)peroxide-bound intermediate, as opposed to two, suggests that the mechanism differs from that of the $D$. baarsii SOR enzyme. ${ }^{1 \mathrm{~b}, 2}$ Possible mechanisms consistent with the proton dependence of the formation of $\mathbf{2}$ would involve either initial protonation of superoxide to afford $\mathrm{HO}_{2}$, a more potent oxidant than $\mathrm{O}_{2}{ }^{-}$, or initial protonation of the thiolate sulfur of $\mathbf{1}$ to afford a dicationic species that has a higher affinity for $\mathrm{O}_{2}{ }^{-}$. More detailed kinetic studies of both the proton-induced formation of $\mathrm{Fe}^{\mathrm{III}}-\mathrm{OOH}(2)$ and the proton-induced release of $\mathrm{H}_{2} \mathrm{O}_{2}$ are currently underway in our laboratory.

\section{Supplementary Material}

Refer to Web version on PubMed Central for supplementary material.

\section{Acknowledgments}

This work was supported by NIH Grant GM45881. We thank Priscilla Lugo-Mas for experimental assistance and Leon $\mathrm{Xu}$ for helpful discussion.

\section{References}

1. (a) Emerson JP, Coulter ED, Cabelli DE, Phillips RS, Kurtz DM Jr. Biochemistry. 2002; 41:43484357. [PubMed: 11914081] (b) Niviere V, Asso M, Weill CO, Lombard M, Guigliarelli B, Favaudon V, Houe'e-Levin C. Biochemistry. 2004; 43:808-818. [PubMed: 14730986] (c) Mathe C, Mattioli TA, Horner O, Lombard M, Latour J-M, Fontecave M, Niviere V. J Am Chem Soc. 2002; 124:4966-4967. [PubMed: 11982354] (d) Jenney FE Jr, Verhagen MFJM, Cui X, Adams MWW. Science. 1999; 286:306-309. [PubMed: 10514376] (e) Coulter ED, Emerson JP, Kurtz DM Jr, Cabelli DE. J Am Chem Soc. 2000; 122:11555-11556.(f) Clay MD, Jenney FE Jr, Hagedoorn PL, George GN, Adams MWW, Johnson MK. J Am Chem Soc. 2002; 124:788-805. [PubMed: 11817955] (g) Silaghi-Dumitrescu R, Silaghi-Dumitrescu I, Coulter ED, Kurtz DM Jr. Inorg Chem. 2003; 42:446-456. [PubMed: 12693226] (h) Yeh AP, Hu Y, Jenney FE Jr, Adams MWW, Rees DC. Biochemistry. 2000; 39:2499-2508. [PubMed: 10704199] (i) Coelho AV, Matias P, Fulop V, Thompson A, Gonzalez A, Carrondo MA. J Biol Inorg Chem. 1997; 2:680-689.(j) Jovanovic T, Ascenso C, Hazlett KRO, Sikkink R, Krebs C, Litwiller R, Benson LM, Moura I, Moura JJG, Radolf JD, Huynh B Hanh, Naylor S, Rusnak F. J Biol Chem. 2000; 275:28439-28448. [PubMed: 10874033]

2. Lombard M, Houee-Levin C, Touati D, Fontecave M, Niviere V. Biochemistry. 2001; 40:50325040. [PubMed: 11305919]

3. (a) Sono M, Roach MP, Coulter ED, Dawson JH. Chem Rev. 1996; 96:2841-2887. [PubMed: 11848843] (b) Makris TM, Davydov R, Denisov IG, Hoffman BM, Sligar SG. Drug Metabolism Reviews. 2002; 34:691-708. [PubMed: 12487147]

4. (a) Harris DL, Loew GH. J Am Chem Soc. 1998; 120:8941-8948.(b) Lehnert N, Neese F, Ho RY, Que L Jr, Solomon EI. J Am Chem Soc. 2002; 124:10810-10822. [PubMed: 12207537] (c) Neese F, Zaleski JM, Zaleski KL, Solomon EI. J Am Chem Soc. 2000; 122:11703-11724.

5. (a) Shearer J, Scarrow RC, Kovacs JA. J Am Chem Soc. 2002; 124:11709-11717. [PubMed: 12296737] (b) Shearer J, Nehring J, Kaminsky W, Kovacs JA. Inorg Chem. 2001; 40:5483-5484. [PubMed: 11599942]

6. Dey A, Chow M, Theisen RM, Kovacs JA, Solomon EI. manuscript in preparation.

7. Kovacs JA. Chem Rev. 2004; 104:825-848. [PubMed: 14871143]

8. When generated from prepurified 1,2 is stable for at least $6 \mathrm{~h}$ at $-78^{\circ} \mathrm{C}$ in THF. Previously (ref 5a), it was reported that intractable solids formed when $\mathrm{O}_{2}{ }^{-}$was added to $\mathbf{1}$ in aprotic solvents. Extreme sensitivity to dioxygen ( $\geq 2 \mathrm{ppm}$ ) and trace amounts water make purification of 1 nontrivial.

9. Bernhard P, Anson FC. Inorg Chem. 1988; 27:4574-4577. 
10. (a) Chin D-H, Chiericato G Jr, Nanni EJ Jr, Sawyer DT. J Am Chem Soc. 1982; 104:1296-1299. (b) Sawyer DT, Gibian MJ, Morrison MM, Seo ET. J Am Chem Soc. 1978; 100:627-628.

11. The $\mathrm{pK}_{\mathrm{a}}$ of $\mathrm{H}_{2} \mathrm{O}_{2}$ is 11.2 in water 15.8 in $\mathrm{MeOH}$ at $25^{\circ} \mathrm{C}$ :Buncel $\mathrm{E}$, Chuaqui C, Wilson $\mathrm{H}$. Int $\mathrm{J}$ Chem Kinet. 1982; 14:823-837.

12. The final products in this reaction were identified via comparison of their electronic absorption spectra with that of authentic samples (synthesized from $\left[\mathrm{Fe}^{\mathrm{III}}\left(\mathrm{S}^{\mathrm{Me} 2} \mathrm{~N}_{4}(\operatorname{tren})\right)(\mathrm{MeCN})\right]^{2+}$ and $\mathrm{Bu}_{4} \mathrm{~N}^{+} \mathrm{OAc}^{-}$): Shearer J, Fitch SB, Kaminsky W, Benedict J, Scarrow RC, Kovacs JA. Proc Natl Acad Sci USA. 2003; 100:3671-3676. [PubMed: 12655068]

13. In the absence of additional kinetic data, we cannot rule out an associative mechanism involving $\mathrm{OAc}^{-}$binding to the solvent-ligated 3 intermediate. 


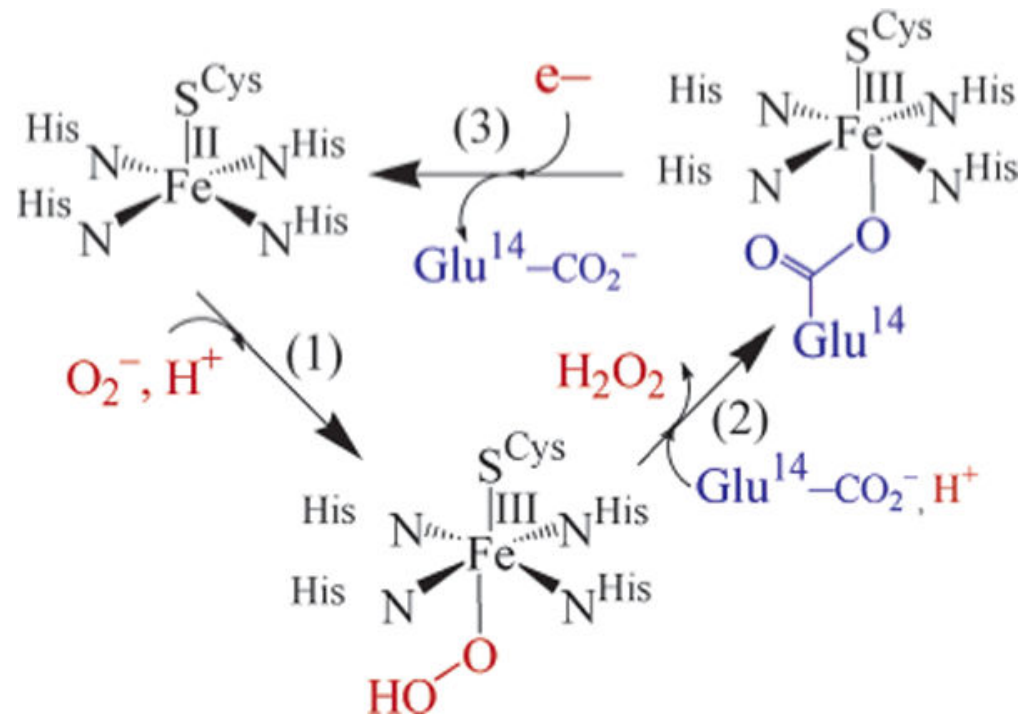

Figure 1.

Proposed mechanism of superoxide reduction by the non-heme iron enzyme superoxide reductase (SOR). 

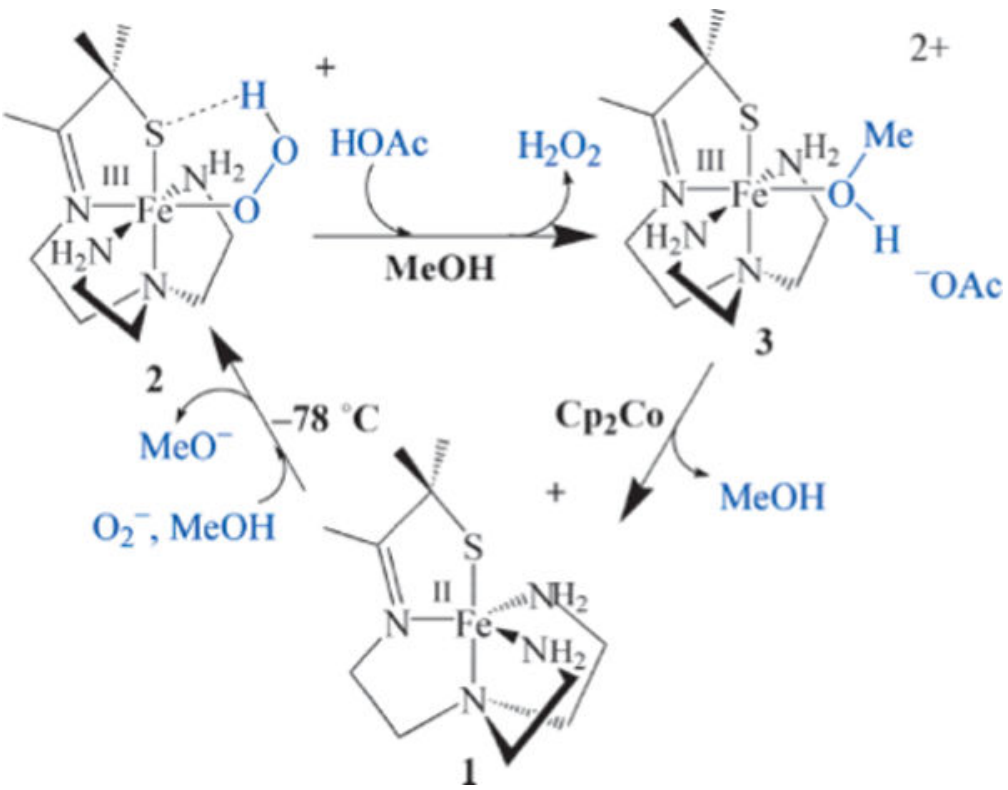

Figure 2.

Biomimetic SOR analogue reduces superoxide in two proton-dependent steps via an Fe $\mathrm{Fe}^{\mathrm{III}}$ $\mathrm{OOH}$ intermediate 2 . The reduced catalyst $\mathbf{1}$ is regenerated via $\mathrm{HOAc}$-promoted $\mathrm{H}_{2} \mathrm{O}_{2}$ release, followed by reduction with cobaltocene. 


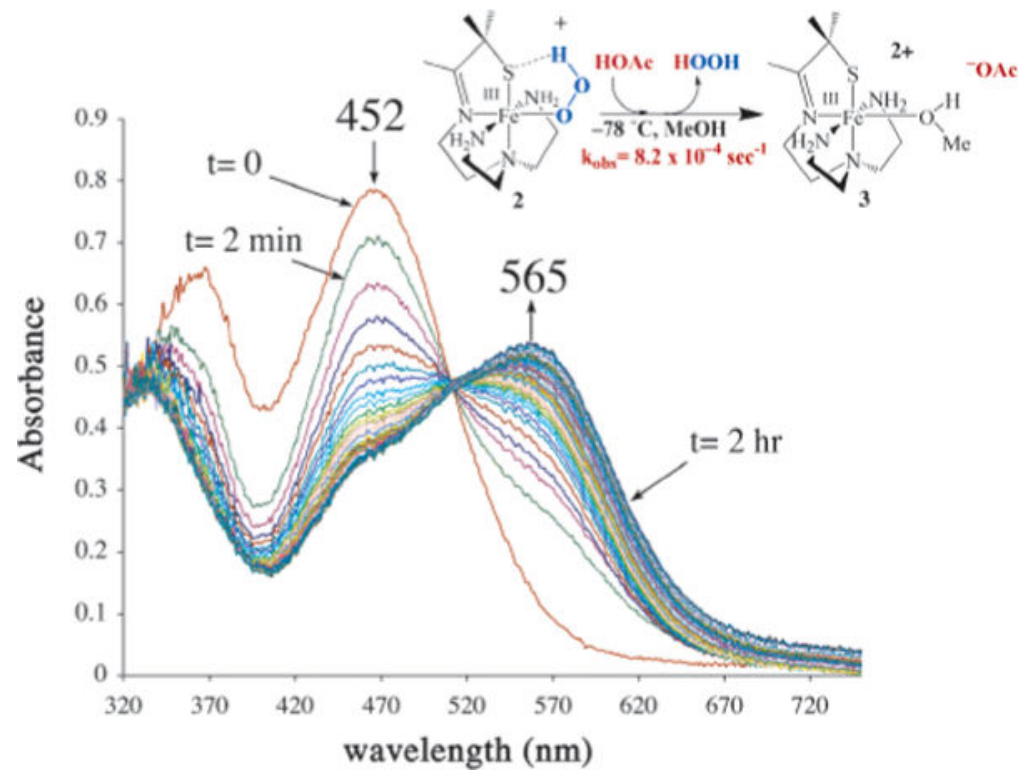

Figure 3.

Reaction between 2 and $\mathrm{HOAc}$ in $\mathrm{MeOH}$ under pseudo-first-order conditions ([HOAc] $=$ $139 \mathrm{mM},[2]=0.49 \mathrm{mM}$ ) monitored via electronic absorption spectroscopy at $-78^{\circ} \mathrm{C}$ (scans taken every $2 \mathrm{~min}$ ). 